
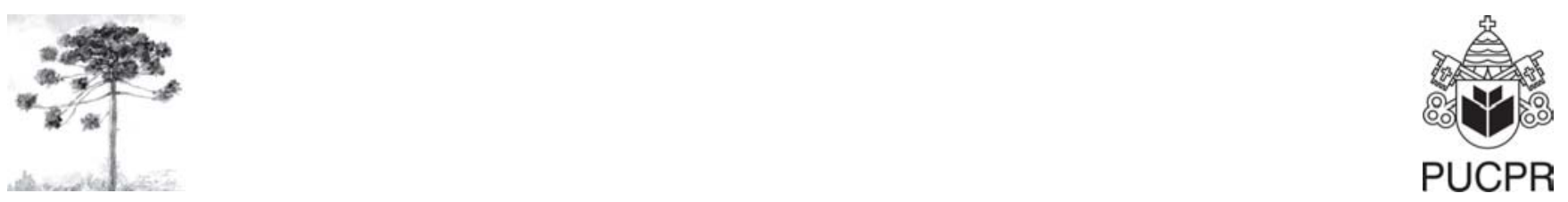

\title{
PETROLEUM PRODUCED (FORMATION) WATER INDUCED CHANGES IN BACTERIAL QUALITY AND SOIL ENZYMATIC ACTIVITIES IN A FARMLAND IN EGBEMA SOUTHERN NIGERIA
}

\author{
Água de petróleo induz alteraçôes na qualidade bacteriana e nas atividades \\ enzimáticas do solo em uma fazenda em Egbema, sul da Nigéria
}

\footnotetext{
Victor Oluoha Nwaugo ${ }^{1}$, Reginald Azuonye Onyeagba ${ }^{2}$, Nelson $\mathrm{Azu}^{3}$, Okoro Nworie ${ }^{4}$

${ }^{1}$ Dept of Microbiology, Abia State University, Uturu - Nigeria, e-mail: vonwaugo@yahoo.com

${ }^{2}$ Dept of Microbiology, Abia State University, Uturu-Nigeria, e-mail: azuonyeagba@yahoo.com

${ }^{3}$ Dept of Microbiology, Ebonyi State University, Abakiliki - Nigeria, e-mail: ancfountains@yahoo.com

${ }^{4}$ Dept of Microbiology, Ebonyi State University, Abakiliki, Nigeria, e-mail: Okoronworie@yahoo.com
}

\begin{abstract}
The effects of petroleum-produced water (PPW) in bacterial population and soil enzymatic activities in cassava farmland in Egbema were investigated. Results obtained showed that the flow carried away soil, silt, organic matter, and total phosphorus and nitrogen creating areas with different impacting degrees. This resulted in lower bacterial prevalence and diversity in heavily impacted soil that increased in moderately impacted. In the lightly impacted soil the results were above the control. Most affected were the nitrifying bacteria followed by the coliforms and the hydrocarbon utilizing bacteria. In other hand, total heterotrophic bacteria were the least affected. Urease has presented 5.8 times higher activity in the lightly impacted soil and 5.4 times in the control than the $0.62 \mathrm{mg} \mathrm{NH}-\mathrm{N} / \mathrm{g} / 24 \mathrm{~h}$ observed in the heavily impacted soil. Dehydrogenases have showed 5.2 times more activity in the lightly impacted soil with only $4.71 \mathrm{mg} / \mathrm{g} / 6 \mathrm{~h}$ in the heavily impacted soil. Hydrogen peroxidase and polyphenol-oxidase have shown similar pattern in all impacting situation. Alkaline phosphatase did not show any significant change in activity while the change in activity of acid phosphatase was very low. PPW therefore affected bacterial quality and soil enzymatic activities adversely when in high quantity but when in low quantity encouraged higher bacterial diversity and soil enzymatic activities.
\end{abstract}

Keywords: Petroleum-produced water; Soil bacterial diversity; Soil enzymes. 


\section{Resumo}

Os efeitos da água de petróleo (PPW) na população bacteriana e nas atividades enzimáticas do solo em uma fazenda produtora de mandioca em Egbema foram investigados. Os resultados obtidos mostraram que o fluxo carreou solo, sedimentos, matéria orgânica e fósforo e nitrogênio totais criando áreas com diferentes graus de impacto. Isso resultou em uma menor prevalência e diversidade bacteriana em solos pesadamente impactados que em solos moderadamente impactados. Em solos levemente impactados, os resultados permaneceram superiores aos dos controles. Os organismos mais afetados foram as bactérias denitrificantes, seguidas dos coliformes e metabolizadores de hidrocarbonetos. Por outro lado, as bactérias heterotróficas totais foram os organismos menos afetados. A atividade de urease foi 5,8 vezes maior em solos levemente impactados e 5,4 vezes maior no controle, que os 0,62 mg de $\mathrm{NH}_{3}-\mathrm{N} / \mathrm{g} / 24 \mathrm{~h}$ observados nos solos muito impactados. Desidrogenases mostraram 5,2 vezes maior atividade em solos levemente impactados contra os $4,71 \mathrm{mg} / \mathrm{g} / 6 \mathrm{~h}$ nos solos pesadamente impactados. Hidrogênio-peroxidase e polifenol-oxidase apresentaram padrões similares de atividade em todas as situações de impacto. Fosfatases ácida e alcalina não apresentaram quaisquer alterações significativas. Os impactos da PPW afetaram a qualidade bacteriana e as atividades enzimáticas de forma adversa quando intensos; mas, quando em baixa intensidade, incrementaram a diversidade bacteriana e a atividade enzimática.

Palavras-chave: Água de petróleo; Diversidade bacteriana do solo; Enzimas de solo.

\section{INTRODUCTION}

Petroleum, when obtained from the earth crust is accompanied by water and gas. While the gas is now liquified, the water is discharged as waste. Petroleum exploration and exploitation, have resulted in various types of environmental pollution $(1,2,3)$. In most cases, the petroleum produced water, like most other petroleum related wastes, is not properly disposed in developing countries $(2,4,5)$.

There is now a growing interest in the changes in Physicochemical and microbial community structure and diversity involving water bodies and lands due to pollution $(6,2,7)$. These changes in soil microbial structure result in changes in soil activities and functions. Petroleum produced water contains some petroleum fractions which could affect microbial life $(3,1,8)$. The soil activities and fertility are based on the soil microbial enzymes as the activities are mainly biogechemical in nature $(6,9,10,11)$. The use of microbial enzymatic activities circumvents the problem of attempting to culture all micro-organisms because some are either unculturable or very difficult to do so (6). Most of the enzymes involved in soil functions and fertility are the oxidoreductase group involving the dehydrogenase, phosphotase, and the oxidase $(12,13)$.
According to Li et al. (6) soil enzymatic activities and microbial diversity are directly related to soil functions. This could be explained in terms of soil health with reference to pollution and usage. This work then assesses the level of some soil enzymatic activities and microbial spectrum in petroleum produced water impacted cassava farmland in Egbema, a community in the Niger Delta Area of Rivers State.

\section{MATERIALS AND METHODS}

The study area is Egbema, a community in Rivers State in the Niger Delta Area of Nigeria. It has all the features of typical Tropical Rain Forest. The area is dotted with Petroleum flow stations owned by the various oil companies operating in the area for over 50 years. The people are mainly farmers and fishermen with few engaged with the various oil companies in the area in different capacity.

\section{SOIL SAMPLES AND DESCRIPTION}

Soil samples were collected from four (4) areas-the heavily, moderately, lightly impacted and an unimpacted site as control. Some physical and chemical properties of the soil samples were 
analysed. These include, $\mathrm{pH}$, moisture, organic carbon and total Nitrogen contents. Others were total Phosphorous, and Potassium. These were done according to Tabatabai (14) as modified by Li et al. (6) and Wyszkowska and Ucharski, (14).

\section{PHYSICOCHEMICAL PARAMETERS OF THE PETROLEUM PRODUCED WATER (PPW)}

The physicochemical parameters of the PPW measured include $\mathrm{pH}$, temperature, Total Dissolved solids (TDS) Total suspended solids (TSS), Dissolved Oxygen (DO) and Biological Oxygen Demand (BOD). Others include sulphate $\left(\mathrm{SO}_{4}\right)$, Phosphate $\left(\mathrm{PO}_{4}\right)$, Nitrate $\left(\mathrm{NO}_{3}\right)$ and some metallic ions ( $\mathrm{k}, \mathrm{Mg}, \mathrm{Co}, \mathrm{Na}$ ). The $\mathrm{pH}$ and temperature were measured in situ using multipurpose tester (Jenway, HANNA 1910 model). The DO was determined using the Winkler's titration method Apha, (15). The $\mathrm{S}_{4}, \mathrm{PO}_{4}, \mathrm{NO}_{3}$, TDS and TSS were determined using the spectrophotometric method with $\mathrm{HACH} / \mathrm{D} 2 / 2010$ spectrophometer. The metallic ions were determined using Atomic Absorption spectroptometric (AAS) method following the method of Apha (15). The oil content of the PPW and the soil samples were determined using the method of Rittman \& Johnson (16) involving pure Hexane extraction process.

\section{MICROBIOLOGICAL STUDIES}

The soil samples from each of the four designated sites were analysed for microbial occurrence using culture techniques. Four groups of bacteria were analysed and include Hydrocarbon Utilizing bacteria (HUB), Total Heterotrophic bacteria (THB), Coliform bacteia (CB), and Nitrifying bacteria (NB) using specific media. The bioload of these bacteria was estimated after decimal serial dilution and inoculation was by spread plate technique. Only plates with 30-100 colonies were used.

\section{SOIL ENZYMATIC ACTIVITIES}

The enzymes whose activities were analysed include dehydrogenase, urease, hydrogen peroxidase, polyphenol oxidase and the phosphotases. (acid and alkaline).

The dehydrogenase was determined as described by Cassida et al. (17). $5.0 \mathrm{~g}$ of soil was mixed with $10 \mathrm{ml}$ of $0.25 \%$ aqueous tripheny 1 tetrazolium chloride (TTC). This was incubated in sealed tubes at $30^{\circ} \mathrm{C}$ for 6 hours. The absorbance at $485 \mathrm{~nm}$ of methanol extracts of the tripheny 1 formazon (TPF) formed was measured using methanol as blank. The result was expressed as $\mathrm{TPFg}^{-1}$ dry soil $6 \mathrm{~h}$.

The urease activity was determined by the colorimetric method based on formation of $\mathrm{NH}_{3}-\mathrm{N}$ in the urea-amended soil samples (after 24 hours incubation at $37^{\circ} \mathrm{C}$ ). This was expressed as $\mathrm{mg} \mathrm{NH}_{3}-\mathrm{Ng}^{-1}$ dry soil $24 \mathrm{~h}(18,19)$.

Soil Hydrogen peroxidase activity was estimated by the $\mathrm{KmnO}_{4}$ titration method. The result was expressed as $\mathrm{ml} .0 .1 \mathrm{~mol} \mathrm{~L}^{-1} \mathrm{KmnO}_{4} \mathrm{~g}^{-1}$ dry soil (20). The polyphenol-oxidase activity was estimated by the colorimetric method. This was based on the purpuragallin formation in the pyrogallic acid-supplemented soil samples. The amended soil was incubated at $30^{\circ} \mathrm{C}$ for 3 hours and the result expressed as mg purpurogallin $\mathrm{g}^{-1}$ dry soil $3 \mathrm{~h}^{-1}$ as described by Ma et al. (6) and $\mathrm{Li}$ et al. (21).

The activities of both acid and alkaline phosphotase were determined as described by Tabatabai and Bremear (22) involving the use of Nitropheneyl phosphate.

\section{RESULTS}

Results of the soil characteristics are shown in Table I. All parameters showed some form of trend. The $\mathrm{pH}$ changed slightly giving a weakly acidic $\mathrm{pH}$ near the discharge/fallout point (DFP) and slightly alkaline at control. Temperature was also highest at the DFP but decreased gradually, though not statistically significant $(\mathrm{P}=0.05)$ (Table 1). The most affected factors were Total N, Total P, and Total organic matter. These were statistically lower in the heavily impacted soil, followed by the moderately impacted but high in the lightly impacted soil. $\mathrm{Mg}, \mathrm{Ca}, \mathrm{K}$, and $\mathrm{Na}$ values were not significantly different in the various soil sample, while oil content was highest at the heavily impacted and lowest in the control. (Table 1). 
TABLE 1 - Soil Characteristic of the various samples examined

\begin{tabular}{lllll}
\hline $\begin{array}{l}\text { Soil } \\
\text { characteristics }\end{array}$ & $\begin{array}{l}\text { Lightly } \\
\text { impacted }\end{array}$ & $\begin{array}{l}\text { Moderately } \\
\text { impacted }\end{array}$ & $\begin{array}{l}\text { Heavenly } \\
\text { impacted }\end{array}$ & Control \\
\hline Clay & $16 \pm 0.20^{\mathrm{a}}$ & $21 \pm 0.30^{\mathrm{b}}$ & $27 \pm 0.40^{\mathrm{b}}$ & $\begin{array}{l}11.00 \pm 0.50^{\mathrm{a}} \\
23.00 \pm 0.40^{\mathrm{a}}\end{array}$ \\
Silt & $21 \pm 0.30^{\mathrm{a}}$ & $18 \pm 0.10^{\mathrm{b}}$ & $15 \pm 0.30^{\mathrm{b}}$ & $66.00 \pm 0.20^{\mathrm{a}}$ \\
Sand & $63+0.30^{\mathrm{a}}$ & $61 \pm 0.20^{\mathrm{a}}$ & $58 \pm 0.20^{\mathrm{b}}$ & $7.5 \pm 0.20^{\mathrm{a}}$ \\
PH & $7.5 \pm 0.20^{\mathrm{a}}$ & $7.1 \pm 0.30^{\mathrm{a}}$ & $6.8 \pm 0.10^{\mathrm{b}}$ & $28.00 \pm 0.10^{\mathrm{a}}$ \\
Moisture & $31 \pm 0.20^{\mathrm{a}}$ & $36 \pm 0.20^{\mathrm{b}}$ & $41 \pm 0.10^{\mathrm{c}}$ & $20.00 \pm 0.03^{\mathrm{a}}$ \\
Organic C & $24 \pm 0.30^{\mathrm{a}}$ & $32 \pm 0.40^{\mathrm{b}}$ & $39 \pm 0.50^{\mathrm{c}}$ & $2.7 \pm 0.20^{\mathrm{a}}$ \\
Total N & $2.9 \pm 0.10^{\mathrm{a}}$ & $1.2 \pm 0.30^{\mathrm{b}}$ & $0.91 \pm 0.50^{\mathrm{c}}$ & $2.1 \pm 0.20^{\mathrm{a}}$ \\
Total P & $2.3 \pm 0.30^{\mathrm{a}}$ & $1.9 \pm 0.50^{\mathrm{b}}$ & $0.82 \pm 0.20^{\mathrm{c}}$ & $0.61 \pm 0.02^{\mathrm{c}}$ \\
Total Petroleum HC & $1.03 \pm 0.10^{\mathrm{a}}$ & $2.1 \pm 0.21^{\mathrm{b}}$ & $2.9 \pm 0.20^{\mathrm{b}}$ & $0.68 \pm 0.30^{\mathrm{a}}$ \\
Mg & $0.69 \pm 0.20^{\mathrm{a}}$ & $0.67 \pm 0.30^{\mathrm{a}}$ & $0.70 \pm 0.20^{\mathrm{ab}}$ & $1.57 \pm 0.30^{\mathrm{a}}$ \\
Ca & $1.57 \pm 0.20^{\mathrm{a}}$ & $1.59 \pm 0.50^{\mathrm{a}}$ & $1.59 \pm 0.10^{\mathrm{a}}$ & $0.09 \pm 0.20^{\mathrm{a}}$ \\
Nn & $0.09 \pm 0.20 \mathrm{a}$ & $0.10 \pm 0.12^{\mathrm{b}}$ & $0.15 \pm 0.13^{\mathrm{b}}$ & $0.31 \pm 0.12^{\mathrm{a}}$ \\
K & $0.32 \pm 0.10^{\mathrm{a}}$ & $0.32 \pm 0.10^{\mathrm{a}}$ & $0.34 \pm 0.20^{\mathrm{a}}$ & 0.34 \\
\hline
\end{tabular}

* Figures followed by the same alphabets are not significantly different but those followed by different alphabets are significantly different

TABLE 2 - Prevalence of bacterial species in the soil samples analysed in percentage

\begin{tabular}{lllll}
\hline Organisms & $\begin{array}{l}\text { Lightly } \\
\text { impacted }\end{array}$ & $\begin{array}{l}\text { Moderately } \\
\text { impacted }\end{array}$ & $\begin{array}{l}\text { Heavenly } \\
\text { impacted }\end{array}$ & Control \\
\hline Pseudomonas sp & 60.00 & 20.00 & 55.00 & 25.00 \\
Bacillus sp & 80.00 & 20.00 & 60.00 & 100.00 \\
Staphylococcus sp & 66.00 & 20.00 & 20.00 & 50.00 \\
Enterobacter sp & 40.00 & 20.00 & - & 60.00 \\
Ecoli & 50.00 & 40.00 & - & 70.00 \\
Alicaligenes sp & 60.00 & 50.00 & 30.00 & 40.00 \\
Flarobacterium sp & 50.00 & 60.00 & 20.00 & 20.00 \\
Micrococcus sp & 60.00 & 40.00 & - & 50.00 \\
Azotobacter sp & 40.00 & - & 30.00 \\
\hline
\end{tabular}

* All figures in mean of ten times isolation Not observed

Table 2 shows the occurrence of the various bacterial species in the soil analysed. Heavily impacted soil had the lowest occurrence and diversity while the highest was in the highly impacted soil, above the control values. Bacillus species was the most prevalent in all soil samples while Pseudomonas, Alcaligenes, Flavobacterium and Micrococcus species were more prevalent in the highly impacted soil. Enterobacter and Azotobacter species were not observed in the heavily impacted soil.

Bioload of the various bacterial groups estimated showed that the most affected was the Nitrifying bacterial species with only $1.2 \times 10^{2}$ in the heavily impacted soil and $3.6 \times 10^{4}$ in the control with $3.9 \times 10^{4}$ in the lightly, impacted soil. The least affected was the Total Heterotrophic bacteria with $4.3 \times 10^{4}$ in heavily polluted soil and $6.4 \times 10^{6}$ in the control. THB in the lightly impacted soil was $6.7 \times 10^{6}$. The Hydrocarbon utilizing bacteria also showed a significant increase in the lightly polluted soil $\left(4.1 \times 10^{5}\right)$ than the heavily impacted soil $(1.4 \mathrm{x}$ $10^{3}$ ) but was lower in the moderately and heavily impacted soil (Table 3). 
Petroleum produced (formation) water induced changes in bacterial quality and soil enzymatic activities in a farmland in Egbema southern Nigeria

TABLE 3 - Biolad of various groups of bacteria estimated

\begin{tabular}{lllll}
\hline $\begin{array}{l}\text { Group of } \\
\text { bacteria }\end{array}$ & Control & $\begin{array}{l}\text { Lightly } \\
\text { impacted }\end{array}$ & $\begin{array}{l}\text { Moderately } \\
\text { impacted }\end{array}$ & $\begin{array}{l}\text { Heavenly } \\
\text { impacted }\end{array}$ \\
\hline THBC & $6.4 \times 10^{6} \pm 0.15^{\mathrm{a}}$ & $6.7 \times 10^{6} \pm 0.20^{\mathrm{a}}$ & $4.4 \mathrm{X} 10^{5} \pm 0.20^{\mathrm{b}}$ & $4.3 \mathrm{X} 10^{4} \pm 0.30^{\mathrm{c}}$ \\
$\mathrm{HUBC}$ & $3.1 \mathrm{X} 10^{4} \pm 0.30^{\mathrm{a}}$ & $4.1 \mathrm{X} 10^{5} \pm 10.20^{\mathrm{b}}$ & $2.4 \mathrm{X} 10^{4} \pm 0.30^{\mathrm{a}}$ & $1.4 \mathrm{X} 10^{3} \pm 0.20^{\mathrm{c}}$ \\
$\mathrm{CBC}$ & $2.5 \mathrm{X} 10^{5} \pm 0.25^{\mathrm{a}}$ & $2.4 \mathrm{X} 10^{5} \pm 0.20^{\mathrm{a}}$ & $1.7 \mathrm{X} 10^{4}+0.20^{\mathrm{b}}$ & $1.1 \mathrm{X} 10^{4} \pm 0.45^{\mathrm{c}}$ \\
$\mathrm{NBC}$ & $2.6 \mathrm{X} 10^{4} \pm 0.20^{\mathrm{a}}$ & $2.8 \mathrm{X} 10^{4} \pm 0.30^{\mathrm{b}}$ & $1.1 \mathrm{X} 10^{4} \pm 0.20^{\mathrm{c}}$ & $1.2 \mathrm{X} 10^{2} \pm 09.70^{\mathrm{d}}$ \\
\hline
\end{tabular}

Figures are mean values of five times estimation

THBC: Total Heterotrophic Bacterial Count

HUBC: Hydrocarbon utilizing Bacterial Count

CBC: Coliform Bacterial Count

NBC: Nitrifying Bacterial Count

Soil enzymatic activity values followed the same pattern with the soil bacterial bioload values. Generally, the lowest enzymatic activities values were observed in the heavily impacted soil, followed by the moderately impacted while the highest were in the lightly impacted, above the control Differences between control and lightly impacted soils were not statistically significantly (P-0.05).

The most sensitive enzyme was urease which had $3.61 \mathrm{mg} \mathrm{NH}_{3}-\mathrm{Ng}^{-1}$ in control (5.8 times higher than the heavily impacted), 3.83 in lightly impacted and only 0.62 in the heavily impacted soil. The dehydrogenase closely followed the Urease in sensitivity. It had the highest value in the lightly impacted soil (34.91), followed by the control (unpolluted) 28.11, while the least was in the heavily polluted soil (4.71). In the control dehydrogenase had 5.2 times more activity than in the heavily impacted soil. Values for the Hydrogen peroxidase and Polyphenol oxidase are also shown in Table 4 and showed similar gradient though not as sensitive as the Urease and dehydrogenase.

TABLE 4 - Soil enzymatic activities in the soil samples examined

\begin{tabular}{|c|c|c|c|c|}
\hline Enzymes & Control & $\begin{array}{l}\text { Lightly } \\
\text { impacted }\end{array}$ & $\begin{array}{l}\text { Moderately } \\
\text { impacted }\end{array}$ & $\begin{array}{l}\text { Heavenly } \\
\text { impacted }\end{array}$ \\
\hline Dehydrogenas & 28.11 & 34.91 & 21.11 & 4.71 \\
\hline$\left(\mathrm{mg} \mathrm{g}^{-1} 6 \mathrm{~h}^{-1}\right)$ & $\pm 0.20^{\mathrm{a}}$ & $\pm 0.50^{\mathrm{b}}$ & $\pm 0.20^{c}$ & $\pm 0.60^{\mathrm{d}}$ \\
\hline Urease & 3.61 & 3.83 & 1.91 & 0.62 \\
\hline$\left(m g g^{-1} 24 h^{-1}\right)$ & $\pm 0.21^{\mathrm{a}}$ & $\pm 0.30^{\mathrm{a}}$ & $\pm 0.50^{\mathrm{b}}$ & $\pm 0.20^{c}$ \\
\hline Oxidase & 0.931 & 1.31 & 5.39 & 8.43 \\
\hline$\left(\mathrm{mg} \mathrm{g}^{-1} 3 \mathrm{~h}^{-1}\right)$ & $\pm 0.20^{\mathrm{a}}$ & $\pm 0.50^{\mathrm{b}}$ & $\pm 0.17^{c}$ & $\pm 0.20^{\mathrm{d}}$ \\
\hline Peroxidase & 1.22 & 2.64 & 6.54 & 11.31 \\
\hline$\left(\mathrm{mg} \mathrm{g}^{-1} 1 \mathrm{~h}^{-1}\right)$ & $\pm 0.30^{\mathrm{a}}$ & $\pm 0.22^{\mathrm{b}}$ & $\pm 0.30^{c}$ & $\pm 0.40^{\mathrm{d}}$ \\
\hline Acid phosphotase & 1.03 & 1.17 & 0.91 & 0.81 \\
\hline ( mol-p-nitrophenol) & $\pm 0.30^{\mathrm{a}}$ & $\pm 0.50^{\mathrm{a}}$ & $\pm 0.20^{\mathrm{b}}$ & $\pm 0.40^{\mathrm{b}}$ \\
\hline $\begin{array}{l}\text { Alkaline phosphotase } \\
\text { ( } \mu \text { mol-p-nitrophenol) }\end{array}$ & 1.56 & 1.54 & 1.46 & 1.32 \\
\hline
\end{tabular}

*Figures followed by the same alphabets are not significantly different but those followed by different alphabets are significantly different 
The least sensitive enzyme was the alkaline phosphotase which did not show any significant difference in its activities in the variously impacted soil. However, the activities of acid phosphotase was slightly significant $(\mathrm{P}=0.05)$ with the highest in the lightly impacted soil (1.17), followed by the control (1.03), moderately impacted (0.91) and Heavily impacted
(0.81). The activities of the enzymes tested correlated negatively with the level of petroleum produced waterimpaction on the soil as the higher the impaction, the lesser the enzymatic activities. Table 5 shows the properties of the PPW from the Discharged Pipe while TTS, TDS, BOD, were above the acceptable unit, DO was below the acceptable unit according to the CEC Directive (23).

TABLE 5 - Physicochemical Parameters of the Petroleum Produced water

\begin{tabular}{|c|c|c|c|}
\hline PARAMETER & VALUE & SQ & RANGE \\
\hline $\mathrm{PH}$ & 7.20 & 0.08 & $7.00-7.28$ \\
\hline Temp. ${ }^{\circ} \mathrm{C}$ & 32.2 & 0.07 & $30.2-32.9$ \\
\hline $\mathrm{TSS} \mathrm{mg} / 1$ & 42 & 3.72 & $40-53$ \\
\hline TDS mg/l & 2820 & 4.30 & $26.10-32.10$ \\
\hline DO mg/l & 4.1 & 0.20 & $3.4-51$ \\
\hline BOD mg/l & 75 & 0.75 & $68-81$ \\
\hline $\mathrm{SO} 4 \mathrm{mg} / 1$ & 29.4 & 0.62 & $28.2-30.1$ \\
\hline PO4 mg/l & 0.11 & 0.03 & $9.9-0.13$ \\
\hline $\mathrm{NO} 3 \mathrm{mg} / \mathrm{l}$ & 30.2 & 0.75 & $27.1-32.5$ \\
\hline $\mathrm{Na}$ & 0.82 & 0.02 & $0.79-8.1$ \\
\hline $\mathrm{Ca}$ & 1.56 & 0.03 & $1.54-1.58$ \\
\hline $\mathrm{Mg}$ & 0.52 & 0.02 & $0.50-0.54$ \\
\hline Oil content mg/l & 2.14 & 0.55 & $2.10-2.50$ \\
\hline
\end{tabular}

*Values stated a means of three times sampling of the pollutant (PPW).

\section{DISCUSSION}

Following the results obtained in this work, the soil physicochemical properties changed slightly with the impaction of the petroleum produced water (PPW). The flow of the PPW carried away the tiny particles (silt) of the soil as it flowed away from the Discharge/Fall out Point (DFP) i.e heavily polluted area. This results in washing away of soil chemicals and components like the Total phosphorus, Total Nitrogen and Organic matter Mantellin and Touraine (24). Nwaugo et al. (2) also reported that water flow carries with it, fine soil particles and chemicals components which can dissolve in the water.

Nwaugo et al. (2) reported that discharge of PPW into the farmland increased the soil moisture content as the soil absorbed the water fraction of the waste. The high oil content of the heavily polluted soil agrees with Wills (3), Nwaugo et al. (25) and Ifeadi et al. (5) that PPW contains some quantities of unrecovered oil. The changes in DO, TDS, TSS, Salinity and BOD of the PPW were high compared to the acceptable standard (CEC Directive $(2,3)$. The metallic ions were within the acceptable levels. This agrees with Wills (3), Nwaugo et al. (2, 25). The PPW is a complex organic waste which requires oxygen for oxidation. It came from under the earth crust noted for low oxygen tension and passed through high temperature (Oxygen expelling process too) during processing of the crude oil hence lacks most of the gaseous components, including oxygen. Wills (2) and Nwaugo et al. (2) agree that high TSS, TDS and other components was caused by the components in the turbid PPW, a similar situation observed in this work.

Occurrence of the bacterial species in the soil at different impaction levels showed that Bacillus species Enterbacter species and E coli were prevalent in the unpolluted soil. However, this situation changed with the introduction of the PPW with Pseudomonas Alcaligenes, Flavobacterium and Micrococcus species becoming more prevalent in the lightly and moderately impacted soil. This could be attributed to substrate-induced change. Bacillus 
species are well known spore-formers hence could survive in most conditions but the proliferation of the bacteria other could be attributed to the PPW. These organisms have been extensively implicated in the bioremediation of oil polluted soil $(2,26,27$, 28) and so tally with this work.

The low bacterial prevalence in the heavily impacted soil indicated that the high amount of PPW also affected the HUB adversely. This meant that the extensive discharge of the PPW disturbed microbial metabolism and proliferation which resulted in low bioload as observed. The lowest bioloads of all groups of bacteria estimated occurred in the heavily impacted soil, followed by the moderately impacted soil. The group most affected was the Nitrifying bacteria. Nitrifying bacteria are obligate aerobes and easily upset by changes in theenvironment $(29,24)$. The PPW altered the growth conditions hence the low bioload. Similarly, coliform (CB) was low in the impacted soil because they could not utilize the PPW. The $\mathrm{CB}$ increased in number in other soil samples when the conditions and other organisms increased indicating that they were depending on the intermediate compounds produced by other organisms-species interdependence. Unlike the Total heterotrophic bacteria which was not much affected, the Hydrocarbon utilizing bacteria were high in moderately and lightly impacted soil only. The THB is a complex group and the sum of all viable bacteria, hence could not be much affected. The HUB increased in bioload, because of the supply of nutrients in the PPW especially in the lightly and moderately polluted soil. This shows that PPW could support microbial proliferation in small quantities but suppressed them when in high amount. The presence of $\mathrm{SO}_{4}, \mathrm{PO}_{4}, \mathrm{NO}_{3}$ in addition to other dissolved and suspended solids along with the unrecovered Hydrocarbon (oil) could be metabolized as nutrients giving higher bacterial prevalence, diversity and bioload.

The use of enzymatic activities in soil analysis gives enormous advantages. Microbial bioload, prevalence and diversity give only the results of culturable species but enzymatic activities ensure that both culturable and unculturable bacterial species are estimated. This means that the activities of both microbial extracellular and intracellular enzymes will be accessed, giving a better analysis $(30,12,6)$.
Microbes and their enzymes are important aspects of the diverse biogeochemical transformation taking place in the soil. The sensitivity of Urease, dehydrogenase and oxidase has resulted in their extensive use in pollution studies $(31,32,6)$.

Dehydogenase, Urease and Oxidase and acid phasphotase negatively correlated with the PPW impaction i.e. higher PPW less enzymatic activities. This work agrees with Ma et al. (21), $\mathrm{Li}$ et al (6) and Pascuall et al (33), that soil pollution reduces soil enzymatic activities. The pollution of the soil with PPW reduced soil DO, brought in oil and other components which disturbed the soil physicochemical and ecological equilibrium. This distortion resulted in low microbial prevalence, diversity and bioload which in turn affected the activities of the enzymes analysed. This work therefore agrees that soil enzymatic activities could be used to access soil health or quality which agrees with Nannipieri et al (34) and Garcia et al (35).

Again, Prescot et al (29) Ma et al (21), and Pascuall et al (33) stated that addition of small quantities of organic matter could activate soil enzymatic activities. This was clearly observed in this work as activities in lightly impacted soil was the highest, even above the control soil. This was further buttressed by the results from the microbial bioload analysed which was highest in the lightly impacted soil. This observation indicated that small quantities of the PPW could be discharged into the farmlands at different points in small amount to increase soil enzymatic activities.

In conclusion therefore, the PPW impaction caused adverse effects only in high quantities in both soil bacterial spectrum and soil enzymatic activities.

\section{REFERENCES}

1. Nwaugo VO, Onyeagba RA, Nwachuwkwu NC. Effects of Gas-Flaring on soil Microbial spectrum in parts of Nigeria Delta Area of Southern Nigeria. Afr J Biotech. 2006a;5(19):1824-1826.

2. Nwaugo VO. Onyeagba RA, Obiekezie SO, Ugbogu OC. Effects of Petroleum Produced water on some farmland soil bacteria in Egbema, Rivers State Int J Biotech. All. Sc. 2006b;1(1):32-36. 
3. Wills JC. A survey of off-shore oil field drilling wastes and disposal techniques to reduces the ecological impact of sea dumping Sakhohin. Environ wate. 2000;13:23-29.

4. Morelli IS, Vecchiolli GI., Del Panno MT, Garre MI, Gostanza OR, Painceira MT. Assessment of the toxic potential of Hydrocarbon containing sludge's. Environ Poll. 1995;89:131-135.

5. Ifeadi, CN, Nwankwo JN, Ekaluo AB, Orubimo II. Treatment and disposal of drilling mud and cutting in the Nigerian Petroleum Industry. Proc. Int. Sem. Petrol. Ind. Nig. Environ. Nigéria: NNPC Lagos; 1985. p. 55-80.

6. Li H. Zhang Y, Zhang CG, Chem GX. Effect of Petroleum-containing waste water irrigation on bacterial diversities and enzymatic activities in a Paddy soil irrigation area. J Environ Qual. 2005;34:1073-1080.

7. Lawton, J.A. What do species do in Ecosystem? Oikos. 1994;71:367-374.

8. Steven DS, James JG, Ketty B, Charles WG. changes in microbial community composition and function during a polyaromatic hydrocarbon phytoremediation field trail. App Environ Microbial. 2003;69:483-489.

9. Killham K, Staddon WJ. Bioindicators and sensors of soil health and the application of geostatistics. In: Burns RG., Dick RP editores. Enzymes in the environment. Activity ecology and application. New York: Dekker/Mariel; 2002. p. 391-394.

10. Dick RD Soil enzyme activities as intergrative indicators of soil halth. In: Pank CE, Hurst BM, Doube VV, Cpupta SR editores. Biological Indicators of soil health. Willingford: CAB; 1997. p. 121-156.

11. Granfreda L. Sannino F. Ortega N, Nannipieri P. Activity of free and immobilized urease in soil. Effects of Pesticides. Soil Biol Biochem. 1994;26:777-784.
12. Wyszkowska, J. \& Kucharski, Y. Biochemical properties of soil contaminated by Petrol. Pol. J. Environ. Stud. 2000;9(6):479485.

13. Prosser, JI Microbial Processes within the soil. In: Von Elsan JD, Trevos JT, Wellington MHE editors. Morden soil Microbiology. New York: Dekker/Marcel; 1997. p. 183-213.

14. Tabatabai MA. Soil enzymes. In: A.L Miller, R.A. \& Kennedy, D.R. (Ed.). Methods of soil Analysis. Chemical \& Microbiological properties. Madison. N.Y: Soil science of American; 1997.

15. APHA, Standard Methods for the examination of water and waste water., $18^{\text {th }}$ ed. Washington: American Public Health Association; 1998.

16. Rittman BE, Johnson NN. rapid Biological Clean-up of soil contaminated with lubricating oil. Wat Sci tech. 1989; 21:209-219.

17. Cassida LE, Klein JD, Santoro D. Soil Dehydrogenase activity. Soil Sc. 1964; 98:371-374.

18. Nannipieri PB, Crescenti S. Cervelli E, Matarese. Extraction of Phosphatase, Urease, Protease Organic carbon and Nitrogen from soil. Soil. Sc Soc Am J. 1980; 44:1011-1016.

19. Kandeler E, Gerber H. Short term assay of soil Urease activity using colorimetric determination of ammonium. Biol Fertil Soils. 1988;6:68-72.

20. Alef K, Nannipieri P Methods in Applied Soil Microbiology and Biochemistry. London: Academic Press; 1995.

21. Ma YJ, Zhang Y, Wong MH. Microbial activity during composting of anthracenecontaminated soil. Chemosphere. 2003; 52:1505-1513.

22. Tabatabai MA, Bremear JM. Use of Pnitrophenyl phosphate for assay of soil phosphates activity. Soil Biol Biochem. 1969;1:307-312. 
23. CEC. Directive Commission of the European Communities council Directive on the protection of the environment and in particular of the soil, when sewage sludge is used in agriculture official J. Eur. Comm. 1986;L181:6.

24. Martellin S, Tauraine B. Plant growthpromoting bacteria and nitrate availability: Impact of root development and nitrate uptake. J Expt Bot. 2004;55(394):27-34.

25. Nwaugo VO, Onyeagba RA, Nwachukwu NC. Moringa Oleitera: a potential biocoagulent in the treatment of petroleum produced water. Nig J Microlbial. 2006c; $20(2)$.

26. Nweke SO, Okpokwasili GC. Drilling fluid Base oil Biodegradation Potential of Staphylococcus species. Afri J Biotech. 2003;2(9):293-292.

27. Kumura B, Murakamin M, Fugisan W. Characteristics and Oil degrading activities of oil Degrading bacteria isolated from the seawater of oil polluted Bisan Sata and Oil Polluted Hibiki Neda. Bull Jap Soc Sc Fishers. 1989;55:10911095.

28. Beinker-Coker MO, Olumigan A. Effects of Drilling fluids on bacterial isolates from a mangrove swamp oil well in the Niger Delta of Nigeria. Biol Res Technol. 1996; 55:175-179.

29. Prescot LM, Harley SP, Klein DA. Microbiology. $5^{\text {th }}$ ed. Boston: McGraw Hill; 2002.

30. Lee I., Kim K., Chang Y., Bae B, Kim HH., Back K. Heavy metal concentrations and enzyme activities in soil from a contaminated Korean showing range. J Bios Biomin. 2002;94(5):406-411.

31. Kuchurski J. Relations between activity of soil enzymes and soil fertility Microorganisms in the environment. A.R Krakow: (Ed. W. Barabasz) Pol Publ; 1997. p. 327-334.
32. Garcia JC, Ploza C, Soler-Rovira P, Ipolo, A. Long term effects of municipal solid waste compost application on soil enzyme activities and microbial biomass. Soil Boil Biochem. 2000;32:1907-1913.

33. Pascual JA, Hernandez C., Garcia, Ayuso, M. Enzymes activities in an arid soilamended with urban organic wastes: Laboratory Experiment. Bioresour. Technol. 1998;64:131-138.

34. Nannipieri PB., Cescanti PS. Greco. Ecological significance of the biological activity in soil. In: Bollag, JM., Stotzky G editores. Spol Biochemistry New York. Mariel/ Dekker; 1990. p. 293-355. v. 6.

35. Garcia C. Hernandez T., Costa F. Potential use of dehydrogenase activity as an index of microbial activity in degraded soils. Comm soil Sc Plant Anal. 1997;28:123-134.

Received: 05/14/2006

Recebido: 14/05/2006

Accepted: $11 / 24 / 2006$

Aceito: 24/11/2006 